\title{
ST. KING LADISLAUS AND THE COUNCIL OF SZABOLCS (1092)**
}

\section{Introduction}

Fundamental changes were brought forth in the IIth century to the situation of Church and politics that so far rested on a framework developed during the previous centuries. ${ }^{\text {I It }}$ was these changes that enabled and mutually helped the expansive efforts of the European states $^{2}$, manifested as a number of military activities, and later - although not directly - as the beginning of the Crusades. ${ }^{3}$ These diverse changes became apparent also in the increasing political strength of the major powers, which resulted in a number of confrontations with the supreme head of the spiritual power, the papacy. ${ }^{4}$ The conflict was already significant in the times of Pope Alexander II (IO6I - I073) $)^{5}$, but it became really powerful only during the reign of Pope Gregory VII (I073 - I085). ${ }^{6}$ It is this milieu in which the systematic

\footnotetext{
* Professor of Canon Law History - Pázmány Péter Catholic University (Budapest). Prof. Szabolcs Szuromi ur. 1972, rektor Katolickiego Uniwersytetu Petera Pazmanya w Budapeszcie, badacz dziejów Kościoła i prawa kanonicznego, mediewista, paleograf.

** This text is an extended version of my presentation at Regum gemma, Ladislae - St. Ladislaus and his cult (Conference in Vác [Hungary], November 9th 2017). Its first publication is edited by the "Rivista internazionale di diritto comune" 28 (2017). The research was supported by the KAP17-63018-3.6-JAK project.

1 R. Bartlett, The Making of Europe. Conquest, Colonization and Cultural Change 950-1350, Harmondsworth 1994, pp. 60-84.

2 G. Constable, Past and Present in the Eleventh and Twelfth Centuries: Perceptions of Time and Change, in: L'Europa dei secoli XI e XII fra novità e tradizione. Sviluppi di una cultura (Miscellanea del centro di studi medioevali 12), Milan 1989, pp. 135-170.

3 R. Bartlett, The Making of Europe, pp. 60-63, 70-72; cf. Riley-Smith, J., The First Crusade and the Idea of Crusading, London-New York 1995; J. France, Patronage and the appeal of the First Crusade, in: The First Crusade. Origins and impact, J. Phillips, (ed.), Manchester-New York 1997, pp. 5-20. C. Kostick, The Social Structure of the First Crusade, Leiden-Boston 2008, pp. 159-186.

4 Cf. U-R. Blumenthal, The Papacy and Canon Law in the Eleventh-Century Reform, "Catholic Historical Review" 84 (1998), pp. 201-218.

5 W. Plöchl, Geschichte des Kirchenrechts, II. Wien-München 19622, pp. 88-89, 10; W. Ullmann, A Short History of the Papacy in the Middle Ages, London 1972, p. 142.

6 Cf. O. Delarc, Saint Grégoire VII et la réforme del'Église au XIe siècle, I-III. Paris 1889-1890; O. Capitas, Episcopato ed ecclesiologia nell'età gregoriana, in: Le istituzioni ecclesiastiche delle societas christiana dei secoli X-XII: papato, cardinalato ed episcopato (Atti della V Settimana Internazionale di Studi Medioevali, Mendola 26-31 agosto 1971; Miscellanea del Centro di Studi Medioevali VII), Milano 1974, pp. 316-373; J. Gilchrist, Gregory VII and the Juristic Sources of his Ideology, "Studia Gratiana" 12 (1967) pp. 3-37; R. Somerville, The Councils of Gregory VII, "Studi Gregoriani” XIII (1989), pp. 33-53; M. Maccarone, I fondamenti "petrini” del Primato romano in Gregorio VII, "Studi Gregoriani”" XIII (1989), pp. 55-122; K. G. Cushing, Papacy and law in the Gregorian Revo-
} 
relation of the Hungarian state and Church was developed. Pope Gregory VII considered the Hungarian monarchs as his natural allies; therefore his surprise was understandable when King Solomon (1063-I074) changed his political direction and in I074 offered Hungary as a vassal state to emperor Henrik IV (I084-IIO5). ${ }^{7}$ Thereafter the pope preferred the promotion of Geza ${ }^{8}$, who was accordingly crowned in I074. After King Geza, in I077, Ladislaus acceded to the throne (I077-I095). Gregory VII already on June 9, IO77 wrote a letter to Nehemiah, the archbishop of Esztergom, expressing his will that the new Hungarian monarch must make a vow to the Apostolic See. ${ }^{9}$ Ladislaus fulfilled the pope's request, made a vow of obedience to "St. Peter" , and from then on right until I092, the king's political activity was in harmony with the international direction that the pope set out. It was King Ladislaus' military expansion in Croatia that caused a breakage in the relations, because Pope Urban II (I088 - I099) did not acknowledge it." This situation disposed Ladislaus to a change in his political direction, and to establish contact with Emperor Henry IV who, in response to a political alliance, was willing to accept the Hungarian conquests. To understand the background of this turn, we must see the complexity of the situation; Henry, the emperor, as long as the Hungarian king was in alliance with the pope, had to recon with a continuous threat from eastward. ${ }^{12}$ Whilst the Hungarian expansion towards the Adriatic See evoked the pope's opposition, because the Croatian ruler - Demetrius Zvonimir (I075 - I089) - received his royal crown right from Pope Gregory VII in I085, what thereby acknowledged the Croatian king's power over the territory of Croatia and Dalmatia that were papal fiefdoms; it similarly threatened the interest of Byzantium, which considered Dalmatia as a part of the Byzantine Empire, and therefore, to defend it, hired mercenaries to track any further Hungarian advancement. In this setting, the Hungarian king Ladislaus indispensably needed the strong military alliance with Henry IV. However, this mutually profitable Hungarian - German alliance meant turning against the Roman Pontiff on political ground. We should place that concrete council, convoked by King Ladislaus in 1092 into Szabolcs, against this background.

\section{Conciliar and Canonical Disciplinary Background in Hungary}

Which council is regarded as the first in the Hungarian history could be the matter of a long debate. It is an unchallenged fact that those "law-books" that are extant under the name

lution. The Canonistic Work of Anselm of Lucca (Oxford Historical Monographs), Oxford 1998; U-R. Blumenthal, The Papacy, 1024-1122, in: The New Cambridge Medieval History, IV/2. D. Luscombe, J. Riley- Smith, (eds.), Cambridge 2004, pp. 8-37; M. Sot, La Réforme Grégorienne. Une introduction, "Revue d'Histoire de l'Église de France" 96 (2010) 5-10. La Reforma Gregoriana en España (Presencia y Diálogo 31), J. M. Magaz, N. Álvarez de las Asturias (eds.), Madrid 2011.

7 Korai magyar történeti lexikon, Gy Kristó (ed.), Budapest 1994, pp. 527, 591; cf. Gy. Kristó, A Kárpát-medence és a magyarság régmúltja, 1301-ig, Szeged 1993, pp. 136-140.

8 Codex Diplomaticus Hungariae ecclesiasticus ac civilis, I. G. Fejér (ed.), Buda 1829, p. 420.

9 Cf. Codex Diplomaticus, I. G. Fejér, (ed.), 443; F. Makk, Magyar külpolitika (896-1196) [Szegedi Középkortörténeti Könyvtár 2], Szeged 1993, p. 94.

10 Pope Gregory VII refers to this concrete answer of King Ladislaus I in his papal letter of March $21^{\text {st }} 1079$ Codex Diplomaticus, I., G. Fejér, (ed.), 445; cf. V. Fraknói, Magyarország egyházi és politikai összeköttetései a Római Szent-Székkel, I. Budapest 190, p. 26.

11 F. Makk, Magyar külpolitika, pp. 113-114.

12 Cf. H. Fuhrmann, Germany in the High Middle Ages c. 1050 - 1200 (transl. T. Reuter), Cambridge 1995, pp. 73-77 . 
of St. Stephan and Andrew I (Constitutiones Ecclesiasticae, seu Decreta sub. Stephano Rege Hungariae; Constitutiones Ecclesiasticae, sub Andrea I. Hungariae Rege [I048]) ${ }^{13}$, contain a number of dispositions concerning the Church (e.g. ecclesiastical property, competence of bishops over ecclesiastical property, the work of the clergy, sanctification of Sunday, obligation of observing ecclesiastical canons, question of ecclesiastical benefices). It is also unquestionable that it was these laws by which the pastoral frameworks of the Catholic Church's domestic work had become established on the legal level, both administrative and financial, as well as of the administration of the sacraments and sacramentals. These laws unequivocally follow the Carolingian form of legislation (i.e. the genre of capitularae) $)^{14}$, that is they contain, in a mixed way, laws issued by the ruler both for the domain of the state and of the Church. ${ }^{5}$ We should list in a similar way those canonical disciplinary regulations that were enacted by Andrew I (I046 - I060). From this aspect - although it was still the person of the ruler convoking it, and its topics of discussion also were characterized by the Carolingian legislation's style - yet, the Council of Szabolcs in 1092 is viewed as a novelty among the sources of Hungarian canonical discipline. Although it is marked in the Corpus Iuris Hungarici as the First Law-Book of St. Ladislaus ${ }^{16}$, yet by textual witnesses it is marked consequently with the word council (synodus): Synodus sub S. Ladislao Hungariae Rege, et Seraphino Archiepiscopo Strigoniensi, habita Szabolchii, An. MXCII. The convention, which is considered in ecclesiastical literature as the first national council - apart of it being convoked and presided by the monarch - was conducted in accord with contemporary conciliar regulations, with the participation of the Hungarian upper hierarchy (bishops and abbots), whose number was made up with the presence of the lords temporal. Regarding its topics of discussion, it provided chapters (capituli), effective for the whole territory of the country, in the whole circle of such ecclesiastical questions as were discussed in contemporary European councils. In advance, we should note that in academic research concerning the early Hungarian legislations and their dates, a number of divergent views are presented, but we do not intend to deal with them here because both the place and the date of the Council of Szabolcs is well known. Instead, we indicate that the legislation under St. Stephan - which Levente Závodszky divides into two law-books ${ }^{17}$ following the structure of the Code of Admont (I2th century) ${ }^{18}$-, in light of recent research, must be viewed as a material most likely born in the framework of various forms of legislation which was enacted on a regular basis (regale concilium, commune concilium, primatum

\footnotetext{
13 Sacra concilia Ecclesiae Romano - Catholicae in Regno Hungariae celebrata, I, C. Péterffy, (ed.), Posonii 1742, pp. 1-13. L. Závodszky, A Szent István, Szent László és Kálmán korabeli törvények és zsinati határozatok forrásai (függelék: a törvények szövege), Budapest 1904 (hereafter: Závodszky), pp. 141-165.

14 P. Erdö, Storia delle Fonti del Diritto Canonico (Istituto di Diritto Canonico San Pio X, Manuali 2), Venezia 2008, pp. 71-72.

15 In detailed, cf. Sz. A. Szuromi, Az egyházi intézményrendszer története (Szent István Kézikönyvek 15), Budapest 2017, pp. 111-114.

16 For the sequenial number and date of origin of the different statute-books cf. Irott források az 1050-1116 közötti magyar történelemböl F. Makk, G. Thoroczkay (eds.), (Szegedi Középkortörténeti Könyvtár 22), Szeged 2006, pp. $85,146-147$.

17 Závodszky 13-14.

18 In detailed, cf. Mikó, G., Szent István király törvényeinek legrégibb kézirata. Az Admonti kódex, in: Arcana tabularii: Tanulmányok Solymosi László tiszteletére, II, A. Bárány, G. Dreska, K. Szovák (eds.), Debrecen-Budapest 2014, pp. 723-732.
} 
conventus, senatus, regalis senatus) $)^{19}$ and became edited into an integral form. The first part of this legislation was composed still during the life of St. Stephan, while the second part, supposedly, in times of Andrew I. ${ }^{20}$

\section{The Importance, Proceeding, and Provisions of the Council of Szabolcs}

Putting the Hungarian national council into a wider context, it is worth to have a look at the precise analysis of Robert Somerville that was published under the title "Pope Urban II's Council of Piacenza". From this work, we can get an accurate picture of the institutional form, participants, and decisive topics of ecclesiastical legislation on the universal level in the last decade of the IIth century. ${ }^{21}$ In his work, Professor Somerville describes not only the characteristics of the concrete council, but also its history of influence and survival in canonical compilations. The first Hungarian national council occurred only three years earlier than the mentioned Council of Piacenza (I095), in I092. In its background there was no initiation to attribute a "general" or "universal" characteristic to it ${ }^{22}$; yet the text of the Council of Szabolcs was left to us as a law-book of St. Ladislaus, which played just as important role in the comprehensive arrangement of the Hungarian ecclesiastical circumstances as the Council of Piacenza played in the universal Church, according to Bernold of Constance (†IIOO) in his Chronicon. Obviously, the impact of the Council of Szabolcs is narrower in its range, but in regard of the Hungarian particular conciliar legislation it is of fundamental importance.

About the convocation of provincial councils the Decretum Burchardi Wormatiensis23which was probably in usage in Hungary in the IIth-I2th century - quoting canon 20 of the Council of Antioch of 3I4 - had a provision, according to which such councils were to be convoked twice a year, the first, after the third week of Easter, the second, on October I5th. ${ }^{24}$ Naturally, in the case of grave necessity, it was possible to convoke further councils, examples for which are election or deposition of a bishop, exercising judicial power. ${ }^{25}$

\footnotetext{
19 "commune concilum" means general assembly in this case, but the "senatus" means Royal council.

20 In detailed, cf. Gy. Kristó, Magyarország története 895-1301, Budapest 1998, pp. 96-97.

21 R. Somerville, R., Pope Urban II's Council of Piacenza, March 1-7, 1095, Oxford 2011.

22 Idem, Pope Urban II's Council of Piacenza, 1, note 2.
}

23 Edition: Patrologiae cursus completus. Series Latina (ed. I-P. Migne, I-CCXXI, Lutetiae Parisiorum 18441864; hereafter: PL) 538-1058; about the collection: H. Hoffmann, R. Pokorny, Das Dekret des Bischofs Burchard von Worms. Textstufen - Frühe Verbreitung - Vorlagen (MGH Hilfsmittel 12), München 1991; G.Austin, Shaping church law around the year 1000. The Decretum of Worms (Church, Faith and Culture in the Medieval West), Aldershot 2009; Sz. A. Szuromi, Peculiarities of the Decretum Burchardi Wormatiensis especially regarding the Discipline about Bishops and their Duties, "Revista Española de Derecho Canónico" 71 (2014), pp. 493-506. About its influence in Hungary in the High Middle Ages cf. Szuromi, Sz. A., Esztergomi zsinatok és kánongyüjtemények a XII. századi Magyarországon, "Iustum Aequum Salutare” II/1 (2006) 191-201; Sz. A. Szuromi, The Influence of the Universal and Particular Conciliar Discipline on the Hungarian Conciliar Legislation in the $11^{\text {th }}-13^{\text {th }}$ Century, "Rivista internazionale di diritto comune "26 (2015) 179-197.

24 BW 1. 44: "Propter utilitates ecclesiasticas et absolutiones earum rerum quae dubitationem controversiamque recipiunt, optime placuit, ut per singulas quasque provincias bis in anno episcoporum concilia celebrentur. Semel quidem post tertiam septimanam festi Paschalis, ita ut in quarta septimana quae consequitur, id est, medio Pentacostes conveniat synodus, metropolitano comprovinciales episcopos admonente. Secunda vero synodus fiat Idibus Octobris, id est XV die mensis Octobris, quem per Beretheon Graeci nominant. In ipsis autem conciliis adsint presbyteri, diaconi, et omnes qui se laesos existimant, et synodi experiantur examen. Nullis vero liceat apud se celebrare concilia, praeter eos quibus metropolitana iura videntur esse commissa." PL CXL. 560-561.

25 About this question in detailed, cf. Sz. A. Szuromi, A püspökökre vonatkozó egyházfegyelmi szabályok a Dionysio-Hadriana gyüjteményben, "Kánonjog" 2 (2000), pp. 87-95, especially p. 90, 93. 
A provincial council had to proceed in the presence of the bishops and of the archbishop. The obligation of convoking two councils yearly appears in Hungary later, among the laws of King Coloman. ${ }^{26}$ Bishops and clerics of other archdioceses or dioceses often appeared at regional councils. This can also be an explanation for the fact that different regional councils many times used almost the same words and sentences in regulations of disputed questions as the council of a neighboring region. This was accompanied also by the strong integral influence of canonical compilations used at the councils. ${ }^{27}$ It is important to note that the clear terminological differentiation between the institution of a concilium, that consists of bishops, and of a synodus, that in diocesan legislation depends on the person of the bishop, first appeared in Const. $6^{28}$ of the Council of Lateran IV (I215) ${ }^{29}$, which Ecumenical Council at the same time put in order also the yearly convocation of diocesan councils.$^{30}$ It was only in the I3th century when, unlike the Carolingian mixed legislation, some Hungarian councils had purely ecclesiastical nature ${ }^{31}$ (e.g., Council of Esztergom in I256; Council of Buda in I 263 and I279) $)^{32}$

${ }_{26}$ Colomanni Regis Decretorum Liber Primus, 2: "Quia populus noster magnis sepe tam vie, quam inopie laboribus pregravatus pro qualibet necessitate curiam regalem adire non potest, bis in anno, id est in festivitate apostolorum Philippi et Jacobi, et in octavis sancti Michaelis synodum in unoquoque episcopatu celebrari constituimus, in qua tam comes et comites, quam reliquorum magistratuum potestates ad suum episcopum conveniant, ad quam quicumque etiam sine sigillo vocatus non venerit, reus iudicii erit.” Závodszky, p. 184; cf. J. Gerics, E. Ladányi, A Kálmán-kori szinodális bíráskodás valószinü mintája, in: Iustum, aequum, salutare. Emlékkönyv Zlinszky János tiszteletére, Budapest 1998, PP.112-115.

27 Sz. A. Szuromi, Az első három Esztergomi Zsinat és a magyarországi egyházfegyelem a XII. században, "Magyar Könyvszemle” 115 (1999), pp. 377-409, especially pp. 377-383; Sz. A. Szuromi, Fejezetek az egyházi jogalkotás történetéböl. Források és intézmények (Bibliotheca Instituti Postgradualis Iuris Canonici Universitatis Catholicae de Petro Pázmány nominatae III/15), Budapest 2011, pp. 86-100.

28 Conc. Lateranense IV (1215), Const. 6: "Sicut olim a sanctis patribus noscitur institutum, metropolitani singulis annis cum suis suffraganeis provincialia non omittant concilia cele brare, in quibus de corrigendis excessibus et moribus reformandis, praesertim in clero, diligentem habeant cum Dei timore tractatum, canonicas regulas et maxime quae statuta sunt in hoc generali concilio relegentes, ut eas faciant observari, debitam poenam transgressoribus infligendo. Ut autem id valeat efficacius adimpleri, per singulas dioeceses statuant idoneas personas, providas videlicet et honestas, quae per totum annum simpliciter et de plano, absque ulla iurisdictione sollicite investigent, quae correctione vel reformatione sint digna, e tea fideliter perferant ad metropolitanum et suffraganeos et alios in concilio subsequenti, ut super his et aliis, prout utilitati et honestati congruerit, provida deliberatione procedant; et quae statuerint, faciant observari, publicantes ea in episcopalibus synodis, annuatim per singulas dioeceses celebrandis. Quisquis autem hoc salutare statutum neglexerit adimplere, a suis beneficiis et executione officii suspendatur, donec per superioris arbitrium eius relaxetur." Conciliorum oecumenicorum decretal, Bologna 1973 (hereafter: COD), pp. 238-237.

29 P. Erdő, Az egyházmegyei zsinat intézménye a történelemben, in P.Erdő, Egyházjog a középkori Magyarországon, Budapest 2001; pp. 19-24; cf. Sz. A. Szuromi, The Constitutions of the Fourth Lateran Council (1215) according to its Theological, Canonical and Historical Aspects, "Rivista Internazionale di diritto comune" 15 (2004), pp. 185-199, especially p. 188.

30 Sz. A. Szuromi, Fejezetek az egyházi jogalkotás történetéböl, p.138.

31 A. Szentirmai, Die ungarische Diözesansynode im Spätmittelalter, "Zeitschrift der Savigny-Stiftung für Rechtsgeschichte, Kanonistische Abteilung” 47 (1961) 266-292; cf. Sz. A. Szuromi, The Influence of the Universal and Particular Conciliar Discipline, p. 189-197.

32 Gy. Kristó (ed.), Korai magyar történeti lexikon, p. 752; cf. L. Waldmüller, Die Synoden in Dalmatien, Kroatien und Ungarn. Von der Völkerwanderung bis zum Ende Arpaden (1311) [Konziliengeschichte A], Paderborn-München-Wien-Zürich 1987, pp. 188-200. 


\section{Proceeding of the Council of Szabolcs}

Proceeding of the council - although the ruler was present - most probably followed the prescriptions of the Ordo de celebrando concilio. Such order can be found first in the very beginning 33 of the Decretales Pseudo-Isidorianae which was compiled around $847-852$, and whose more than half is forged. ${ }^{34}$ This order of proceeding of councils was widespread in all Europe and became inserted into those manuscripts of canonical compilations that were used in the diocesan curial practice in the I2th-I3th centuries. One of the best examples for these is the BAV Barb. lat. 535 manuscript ${ }^{35}$ which is a textual version of the Collectio Anselmi Lucensis (I08I-I083) ${ }^{36}$. Moreover, this order was copied even later on, as it is witnessed by the manuscripts of Collectio Anselmi Lucensis, by BAV Reg. Lat. 325 in the I5th century and by Paris Bibliothèque Nationale lat. $\mathrm{I} 2450$ in the I6th century. ${ }^{37}$ This order was used also at the Hungarian Council of Udvard in $1307^{38}$

Bishops, priests, deacons, and the notaries entered the council, according to the order, in a determined (ordination) sequence. The council started with a prayer recited by the archdeacon. ${ }^{39}$ After reciting the Creed and the exhorting words of the archbishop, the discussion of each question began. Following that, the negotiations on the final text of each canon, that was meant to be fixed, was read out for the assembly. The Council was closed with the promulgation of the decrees and by reciting a prayer of thanksgiving..$^{40}$ In the Council of Szabolcs the rules of the order was complemented with certain forms of proceedings and paying homage with regard to the presence of King Ladislaus I and secular dignitaries.

The council in its topics - according to late textual witnesses $\left(15^{\text {th }}-\mathrm{I} 6^{\text {th }}\right.$ centuries $)$ - touched upon the question of married clerics, of paying tithe, of defending ecclesiastical wealth,

\footnotetext{
33 Decretales Pseudo-Isidorianae et Capitula Angilramni, P. Hinschius (ed.), Lipsiae 1863 (repr. Aalen 1963; hereafter: Hinschius), pp. 22-24.

34 A. Stickler, Historia iuris canonici latini. I. Historia fontium, Roma 1950, pp. 131-140; L. Kéry, Canonical Collections of the Early Middle Ages (ca. 400-1140). A Bibliographical Guide to the Manuscripts and Literature (History of Medieval Canon Law I), Washington, D.C. 1999, pp. 100-114; P. Erdö, Storia delle Fonti del Diritto Canonico, pp. 81-83.

35 L. Fowler-Magerl, Clavis Canonum. Selected Canon Law Collections Before 1140 (MGH Hilfsmittel 21), Hannover 2005, pp. 157-158.

36 Sz. A. Szuromi, Anselm of Lucca as a Canonist. Critical summary on importance of the Collectio Anselmi Lucensis, "Rivista internazionale di diritto commune" 16 (2005), pp. 225-239; cf. Sz. A. Szuromi, Anselm of Lucca as a Canonist (Adnotationes in Ius Canonicum 34), Frankfurt am Main 2006, pp. 47-54.

37 Cf. Sz. A. Szuromi, Some observations on BAV Reg. lat. 325 as a witness of Anselm of Lucca's Collection, "Ius Ecclesiae" 15 (2003), pp. 799-810.

38 Sz. A Szuromi, Szempontok az 1307. évi Udvardi Zsinat kánonjogtörténeti vonatkozásaihoz, "Iustum Aequum Salutare" IX/2 (2013) 105-110, especially 108-109.

39 Cf. “(...) Adsumus, domine sancte spiritus, adsumus peccati quidem immanitate detenti, se din nomine tuo specialiter aggregati; veni ad nos et esto nobiscum et dignare illabi cordibus nostris, doce nos quid agamus, quo gradiamur, et ostende quid efficere debeamus, ut te auxiliante tibi in omnibus placere valeamus. Esto salus et suggestor et effector iuditiorum nostrorum, qui solus cum deo patre et eius filio nomen possides gloriosum. Non nos patiaris perturbatores esse iustitiae, qui summam diligis aequitatem, ut in sinistrum nos non ignorantia trahat, non favor inflectat, non acceptio muneris vel ersonae corrumpat; sed iunge nos tibi efficaciter solius tuae gratiae dono, ut simus in te unum et in nullo deviemur a vero, qualiter in nomine tuo collecti, sic in cunctis teneamus cum moderamine pietatis iustitiam, ut et hic a te in nullo dissentiat sententia nostra et in futuro pro bene gestis consequamur praemia sempiterna". Hinschius 22.

40 Cf. “(...) Ad te, domine, interni clamoris vocibus proclamantes unanimiter postulamus, ut respectu tuae gratiae solidati praecones virtutis efficiamur interpidi tuumque valeamus verbum cum omni fiducia loqui." Hinschius 24.
} 
the state of the religious, abbots, as well as bishops, of matrimonial discipline, of prescriptions of teaching on sacraments, of liturgical regulations, as well as of issues of procedural law. ${ }^{41}$

\section{Provisions of the Council of Szabolcs}

a) Text of the Council

Before presenting the interrelations of the content and context of the individual canons, we must indicate that modern research - despite that the eight survived textual witnesses (15th century: Codex of Budai János and Codex of Thuróczy; I6th century: Codex of Kollár, Codex of Ilosvay, Codex of Gregoriánczi, Codex of Nádasdy, Codex of Festetics, and Codex of Besztercebánya) ${ }^{42}$ do not contain significant discrepancies with regard to the introduction and the content of the forty-two chapters - is split in answers to the question if it is the text of only one council, or are we rather talking about a compilation of St. Ladislaus' legislation concerning the Church. Chapters XLI and XLII in any case seem to be a supplement and the sequence of the conciliar dispositions cannot be considered thematically even. ${ }^{43}$ We should note that this thematic unevenness does not exceed the level which can be experienced in contemporary Western and Middle European particular conciliar textual witnesses. We compared the text of the Council of Szabolcs against the incipit catalogue which was compiled by Horst Fuhrmann ${ }^{44}$, as well as on its ground against the text of Decretales Pseudo-Isidorianae published by Paul Hinschius. ${ }^{45}$ From this comparison, it can be ascertained unequivocally by textual critique that the in chapters of the Council of Szabolcs no Pseudo-Isidorian influence can be detected. We made a similar examination concerning the text of Decretum Burchardi Wormatiensis. ${ }^{46}$ From 42 chapters, we could identify textual witness sameness in 9 cases with the text of Burchard's compilation. Further, one chapter is close to the text of the Collectio Dionysio-Hadriana ${ }^{47}$, and another one to the work of Regino of Prüm, titled Libri duo synodalibus causis (about 906) ${ }^{48}$, the source of which is nevertheless used also by Burchard. ${ }^{49}$

\footnotetext{
41 Závodszky, op.cit., pp. 158-165.

${ }^{42}$ Cf. G. Mikó, Szent István törvényeinek XVI. századi kézirata Lö́cse város levéltárában, Fons: "Forráskutatás és történelmi segédtudományyok" 18/2 (2011), pp. 111-145.

${ }^{43}$ About the listed manuscripts in detailed, cf. Makk, F. - Thoroczkay, G. (eds.), Írott források az 1050-1116 közötti magyar történelemböl, pp. 146-147.

${ }^{44}$ Fuhrmann, H., Einfluss und Verbreitung der pseudoisidorischen Falschungen, III (MGH Schriften XXIV/3), Stuttgart 1974, pp.784-1005.

45 Decretales Pseudo-Isidorianae et Capitula Angilramni, P. Hinschius, (ed.), Lipsiae 1863 (repr. Aalen 1963).

46 PL CXL, pp. 538-1058.

47 PL LXVII, pp. 139-316.

48 PL CXXXII, pp. 183-400; R. G. A. Wasserschleben, Reginonis abbatis Prumiensis Libri duo de synodalibus causis et disciplinis ecclesiasticis, Leipzig 1840 (repr. Graz 1964).

49 About the collections which had been used for the Decretum Burchardi Wormatiensis, cf. M. Kerner, F. Kerff, R. Pokorny, K.G. Schon, H. Tills, Textidentifikation und Provenienzanalyse im Decretum Burchardi, in Melanges G. Fransen (Studia Gratiana XX [1976]) 19-63.
} 
b) The Content of the Council's Chapters and their Textual Correlation

Reviewing the themes of chapters of the Council of Szabolcs, we can divide them into seven major groups. We mention firstly Chapters I-IV ${ }^{50}$ texts of which regulate the married and remarried deacons and priests. In a similar way, a separate group is formed by the definition of paying tithe, in regard of which, Chapter XL is the most important, describing the obligation of paying general tithe.$^{5 \mathrm{I}}$ Furthermore, here we should mention the arrangement of tithe concerning free persons (liber) subordinated to an abbot (Chapter XXVII) ${ }^{52}$, and the arrangement of tithe to be paid by free persons of a bishop (Chapter XXX) $5^{3}$ The fixing of distribution of tithe that is due to cattle coming from a different diocese's territory (Chapter XXXIII) can be listed in the topic of paying tithe.54 The third group encompasses Chapters V-VI end XXIII-XXIV which concern the protection of ecclesiastical wealth ${ }^{55}$, as well as Chapters VII-VIII that are connected with this topic dealing with the restoration of ruined churches. Concerning the power of a bishop, chapter XVII ${ }^{66}$ arranging the obligations of foreign clerics, and its complementation chapter XVIII ${ }^{57}$, belong into the forth group of questions. Further chapters touch upon the relation of jurisdictions of bishops and abbots to each other - or to the ruling dynasty - (Chapters XXI, XXXV-XXXVI, and XXXIX ${ }^{58}$ ). The fifth group consists of the marital disciplinary questions which concern more areas, including those cases that belong to the impediment of disparity of cult (Chapters IX-X $\mathrm{X}^{59}$ ), as well as the case of someone doing anything against the unity of marriage (Chapter XX) ${ }^{60}$, or Chapter XIII adjudging and sanctioning one's conjugicide. ${ }^{61}$ In the everyday life of the church, the area of liturgical laws receives a specific emphasis - the sixth group - underlining the compulsory character of observing Sundays and solemnities, which is already present at St. Stephan's law-books (Chapters XI, XII, XV, XVI, and XXVI' ${ }^{62}$ ). Further, we find in this group also those dispositions that concern the area of discipline of burial (Chapter XXV) ${ }^{63}$, the place of celebrating masses (Chapter XXIX) ${ }^{64}$, the obligation of observing the fasting days (Chapter $\mathrm{XXXI})^{65}$, the vigils of the solemnities of saints, and the exact order to celebrate ecclesiastical solemnities and their itemized list (Chapters XXXVII-XXXVIII) ${ }^{66}$. All these are supplemen-

\footnotetext{
Závodszky 158-159.

51 Ibidem, p. 164-165.

52 Ibidem, p. 162.

Ibidem.

54 Ibidem, p. 163.

55 Ibidem, p. 159, 161-162.

56 Ibidem, p. 161.

57 Ibidem.

58 Ibidem, p. 161, 163, 164.

59 Ibidem, p. 159.

60 Ibidem, p. 161

${ }^{61}$ Ibidem, p. 160.

62 Ibidem, p. 160, 162.

63 Ibidem, p. 162.

64 Ibidem.

65 Ibidem, p. 163.

66 Ibidem, p. 163-164.
} 
ted with the seventh group, which arranges certain problems of procedural and penal law. Among these problems, we should emphasize the statement on ordeals (Chapter XXVIII) ${ }^{67}$, which mentions the active presence of a priest and also his wage (two pensa for fire ordeal, one pensa for hot water ordeal). This demonstrates well the ecclesiastical disciplinary incertitude that existed from the IIth until the end of the I2th century in this question, even within the universal canonical discipline and also in its interpretation. ${ }^{68}$ The conciliar text touches upon the summons occurring by sending royal or judicial seal which had convincing authority also for illiterates (Chapter XLII) ${ }^{69}$, however - in contrast with Canon $20^{70}$ of the Council of Esztergom I (IIOO or IIO4/IIO5) $)^{71}$ - it does not mention whether it is "the seal of the bishop or of the archbishop" in question. Here we must refer on the punishment for violence against women in Chapter $\mathrm{XXXII}^{72}$, as well as on the regulations of sitting in judgement over courtesans and witches (Chapter XXXIV)..$^{73}$ Examining textual influences on the mentioned chapters - beyond the above referred canonical collections - there can be identified the Capitulatio de partibus Saxoniae74, the Capitulum Originis Regis a Walterio ${ }^{75}$, the Capitula Synodalia Ottonis I (948) ${ }^{76}$, the Capitula Attonis episcopi Vercellensis (958960) ${ }^{77}$, the Council of Mainz (888) ${ }^{78}$, the Council of Rome (I078) ${ }^{79}$, and the Council of Melf

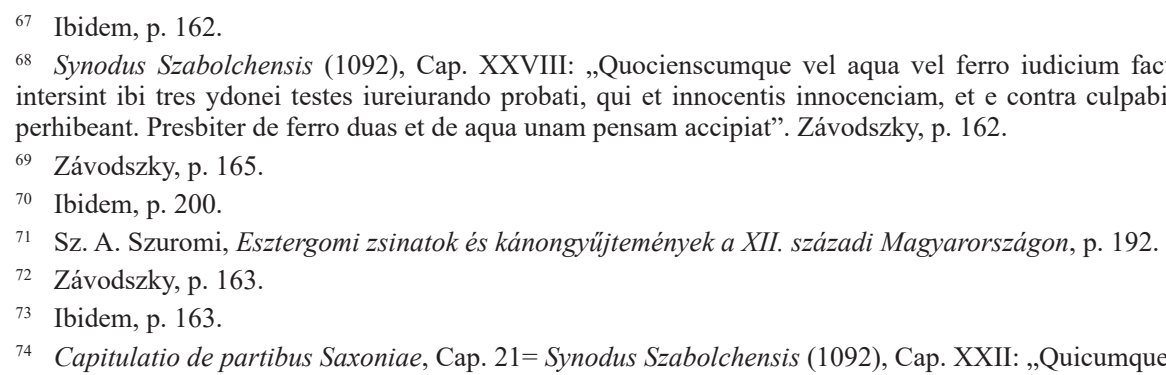

Capitulatio de partibus Saxoniae, Cap. 21= Synodus Szabolchensis (1092), Cap. XXII. „Quicumque ritu gentilium iuxta puteos sacrificaverint, vel ad arbores et fontes et lapides oblaciones obtulerint, reatum suum bove luant. Závodszky 161; Capitulatio de partibus Saxoniae, Cap. 22=Synodus Szabolchensis (1092), Cap. XXV: Si quis dominicum diem non servaverit et dies festos non feriaverit aut quatuor tempora et vigilias non ieiunaverit, aut mortuos suos ad ecclesiam non sepellierit, XII die sin pane et aqua peniteat in cippo. Si dominus servi sui corpus, aut villicus pauperis hospitis vel villani ad ecclesiam non detullerit, tantumdem peniteat." Závodszky, p. 162.

75 Capitulum Originis Regis a Walterio, Cap. 15=Synodus Szabolchensis (1092), Cap. XVI: "Si quis die dominica mercatum constituerit, precipit sancta sinodus, ut sicut construxit, ita destruat. Si autem quis rennuit, quinquaginta quinque pensas solvat.” Závodszky, p. 160.

76 Capitula Synodalia Ottonis I (948), Cap. 10= Synodus Szabolchensis (1092), Cap. XX: "Si quis uxorem suam in adulterio deprehenderit et in iudicium statuerit, secundum statuta canonum penitencia imponatur et peracta penitencia, si maritus voluerit, iterum recipiat, sin autem, quamdiu ambo vixerint, innupti permaneant." Závodszky, p. 161.

77 Capitula Attonis episcopi Vercellensis (958-960), Cap. XXIX= Synodus Szabolchensis (1092), Cap. XIV: "Si quis de calendis sine presbiteri sui et fratrum licencia subtraxerit, manumeam, cum qua fraternitatem promisit, decem pensis redimat." Závodszky, p. 160.

78 Conc. Moguntinum (888), Can. 9= Synodus Szabolchensis (1092), Cap. XXXI: "Latini, qui Hungarorum consuetudini legittime consentire noluerint, scilicet, qui postquam Hungari carnes dimiserunt, ipsi itrum in secunda et tercia feria comederint, si se nostre consuetudini meliori non consenserint, quocumque volunt, eo vadant. Pecuniam vero, quam hic acquisierunt, hic relinquant, nisi forte resipuerint et carnes nobiscum dimiserint." Závodszky, p. 163.

79 Conc. Romanum (1078), Can. 12= Synodus Szabolchensis (1092), Cap. XI: "Si quis in dominicis diebus aut in maioribus festivitatibus ad ecclesiam non venerit parochianam, verberbis corripiatur. Si vero ville remote fuerint et ad ecclesiam suam parochianam villani venire non potuerint, unus tamen ex eis in vice omnium cum baculo ad ecclesiam veniat, et tres panes et candelam ad altare offerat." Závodszky, p. 160. 
$(\text { Io90 })^{80}$. The above-mentioned Capitulatio de partibus Saxoniae $8 I$ - issued by Charlemagne between 782-795 -, the "Capitulum", and the appearance of the German imperial or royal genre of "Constitutiones" and its probable effect on the content of the Council of Szabolcs, unequivocally proves the knowledge of the material of Corpus Iuris Germanici Antiqui ${ }^{82}$, as well as the Frank and German imperial and royal legislations. ${ }^{83}$ This close contact also gives a well-founded support to the disciplinary particularities of the dispositions of the single chapters, to their dependence on the German legislation, as well as to its imperial-council character.

Among the listed groups, we should in greater details touch upon the topics of the married as well as the remarried deacons and priests; the regulation of tithe; the arrangement of the feast days of the saints; and the topic of ordeals.

I. Discipline contained in Chapters I-IV, concerning remarried deacons and priests, priests living in marriage with their maidservants, priests that were ordained as living in marriage, priests living with a widow, and bishops living in marriage, is not in line with the canonical discipline enacted by the Gregorian reform. From the text of the chapters, it is clear that they forbid only the married state of a bishop, and a new marriage after deacon ordination, or after having been widowed his subsequent cohabitation even with a widow. From this point of view, Chapters I and III clearly express that priests and deacons could have a wife, with whom they could live together, except in the case of a maidservant. ${ }^{84}$ We would like to emphasize that Chapter II talks explicitly about a maidservant married to a priest at his very parish, and not about a maidservant taken to him "instead of a wife" ${ }^{85}$, because the text uses the term "uxor" and not "concubina" ${ }^{86}$ Authors most of the times explain this standpoint of the Council of Szabolcs - despite of Chapter III that contains explicitly that in the case of married priests, they should wait for the advice of the pope - with

\footnotetext{
80 Conc. Melfitanum (1090), Can. 12=Synodus Szabolchensis (1092), Cap. IV: "Si quis autem episcopus aut archiepiscopus ab illicitis coniungiis separari nolentibus, spreto sinodali decreto aut consensum prebuerit, aut ecclesiam dederit, aut aliquid, quod ad ordinem pertinet, agere permiserit, a rege et coepiscopis suis secundum, quod racionabile vedetur eis, diiudicetur. Si vero archipresbiter causa ignorancie episcopo consenserit aut presbiter per consensum illius in tali vicio permanserit, iudicio episcopi voluntario subiaceat." Závodszky, p. 159.

81 In detailed, cf. Faulkner, Th., Law and Authority in the Early Middle Ages. The Frankish leges in the Carolingian Period, Cambridge 2016, pp. 46-47.

82 Cf. Walter, F. (ed.), Corpus Iuris Germanici Antqui, III. Berolini 1824.

83 Cf. Weiland, L. (ed.), Constitutiones et acta publica imperatorum et regum inde ab a. DCCCCXI usque ad a. MCXCVII (911-1197) [MGH Constitutiones et acta publica imperatorem regum, I], Hannoverae 1893 (repr. 1963 ; 2003).

84 Synodus Szabolchensis (1092), Cap. I: "Bigamos presbiteros et dyaconos, et viduarum vel repudiatarum maritos iubemus separari, et peracta penitencia ad ordinem suum reverti. Et qui noluerint illicita coniugia dimittere, secundum instituta canonum debent degradari. Separatas autem feminas parentibus suis iubemus reddi et quia non erant legittime, si voluerint, liceat eis maritari." Závodszky, p. 158. Synodus Szabolchensis (1092), Cap. III: "Presbiteris autem, qui prima et legittima duxere coniuga, indulgencia ad tempus datur propter vinculum pacis et unitatem sancti spiritus, quosque nobis in hoc dimini apostolici paternitas consilietur.” Závodszky, p. 158.

85 F. Makk, G. Thoroczkay, (eds.), Írott források az 1050-1116 közötti magyar történelemböl, 148 (the Hungarian translation here is inaccurate).

86 Synodus Szabolchensis (1092), Cap. II: "Si quis autem presbiter ancillam suam uxoris in locum sibi associaverit, vendat; et si noluerit, venumdetur tamen, et precium eius ad episcopum transferatur." Závodszky, p. 158.
} 
its similarity to the canons of the Council of Trullo in $692^{87}$. Those several arguments which trace back the activity of married priests to the Greek canonical discipline in Hungary, despite all facts worth considering ${ }^{88}$, are not sufficiently convincing. Here, we would like to refer again to the motive of the political direction-change of St. Ladislaus, that is, to the conquest of the Croatian and Dalmatian territories. This step was as injurious to Byzantium as to the papal diplomacy, especially in the way, that it was achievable only in alliance with Henrik IV, whose politics alone brought the recognition of Clement III antipope (IO84-IIOO). ${ }^{89}$ Thus, on the level of canonical discipline, a simpler and clearer picture appears to us with the acceptance of the statement, St. Ladislaus fundamentally did not have an intention to rule his country with observing the Gregorian reforms.$^{90}$ This is clearly visible in the decrees of the Council of Szabolcs, even in areas, where it definitely follows Frank and German examples of the 8th-Ioth centuries, moreover it follows the imperial-council even with textual similarities and with the order of legal regulations, taken from the above referred Frank and German collections. In light of these facts - despite of the opinion accepting the dominant Greek influence even in most recent researches ${ }^{91}-$ we still keep our considered and many times explained opinion. According to it, behind the chapters and canons concerning married priest in Hungary, we should look for a canonical collection, in which we cannot find canons enacted against the ordination of married men. Based on those comparative textual critical analyses which we have already made regarding the Councils of Esztergom I and II (III2) ${ }^{92}$, and also about the above mentioned considerable observations on the text of the Council of Szabolcs, it is well supported that this very canonical collection is most probably the Decretum Burchardi Wormatiensis, whose Book II, with the title De presbyteris, diaconibus, et ministris inferioribus, is in full harmony with the canonical disciplinary decrees of the Council of Szabolcs concerning priests. ${ }^{93}$

2. In Hungary, paying general tithe to the diocese was enacted by St. Stephan in his Law-Book II. ${ }^{4}$ Further, St. Ladislaus in Chapters XXVII and XXX of his Law-Book I - of the Council of Szabolcs - gave orders on the obligation of tithe and its specific conditions. ${ }^{95}$ We must add that paying tithe extended not only to products, cattle,

\footnotetext{
87 Cf. N. Dură, The Ecumenity of the Councill in Trullo: Withesses of the Canonical Tradition in East and West, in: G. Nedungatt, M. Featherstone, (eds.), The Council in Trullo revisited (Kanonika 6), Roma 1995, pp. 229-262.

88 Recently, cf. L. Komáromi, A bizánci hatás kérdése a középkori magyar jogban és a magyarországi egyházjogban, Budapest 2013, pp. 104-120.

89 F. Makk, Magyar külpolitika, pp. 92-102.

90 Cf. F. Makk, Magyar külpolitika, pp. 104-105.

91 L. Komáromi, A bizánci hatás kérdése a középkori magyar jogban, pp. 273-274.

92 Sz. A. Szuromi, The Influence of the Universal and Particular Conciliar Discipline, pp. 179-197.

93 PL CXL, pp. 626-666.

94 S. Stephani Decretorum liber secundus, Cap. XVIII: "Si cui deus decem dederit in anno, decimam deo det; et si quis decimam suam abscondit, novem solvat. Et si quis decimacionem episcopo separatam furatus fuerit, diiudicetur ut fura c huiusmodi composicio tota pertineat ad episcopum.” Závodszky, p. 156.

95 Cf. Synodus Szabolchensis (1092), Cap. XXX: "Episcopi de liberis accipiant decimam; liberi vero, cuicunque episcopo vel comiti adheserint, sicut eis placuerit, ita habeantur, salva tamen libertate. Qui autem pro animarum salute libertate mancipati fuerint, eo tenore tamen, ut ecclesie serviant, ipsi nemini, nisi soli presbitero administrant." Závodszky, p. 162.
} 
etc., but revenue of royal customs, coinage, and money exchange were also subject to tithing for the Church. It must be also established that a number of exemptions from paying tithe appeared. The first to be mentioned were those nobilities who had serfs (following the Council of Constance [I4I4-I4I8] also those having no serf were exempted).$^{96}$ Special consideration was given to those territories that originally were not qualified as fertile, such as marshlands and forests. In case they became fertile for agriculture by cultivation, generally even then they remained exempt of paying tithe, especially in cases where they were cultivated by religious people. ${ }^{97}$

3. Regulation of the feasts of saints was in the greatest possible harmony with the principles ascertained in the Decretum Burchardi Wormatiensis, as well as with the list of feast days in it. Chapters XI-XII, XV-XVI explicitly defend the dignity of being dedicated to God and the solemn character of Sundays, as we can find it also in BW 2. 62-63, 70-7I, 73-76, and in BW 2. 8I-88. Chapters XXXVII-XXXVIII give the name of those feasts of saints that have foregoing vigils, and the also names those feasts, whose observation is an obligation, and promote the strengthening of an active religious life of the faithful, as well as - besides the observation of Sundays a continuous faithful and prayerful life. The two mentioned chapters prescribe three vigils and thirty obligatory feasts. The list of feasts follows most probably canon 77 of BW $2^{98}$, complemented with the Hungarian saints. ${ }^{99}$

4. For questions regarding the church's participation in applied procedures of contestations in secular penal cases unequivocal answer was not given even in the IIth century, which is adequately witnessed by Chapter XXVIII of the Council of Szabolcs..$^{100}$ However, at the end of the I2th century, one of the greatest decretalists, Hugh of Pisa $(\dagger 1210)^{\mathrm{I01}}$, took a clear stand against any form of ecclesiastical participation ${ }^{\mathrm{102}}$, whose opinion was officially approved by Pope Innocent III in his letters written in I206 and I2II. ${ }^{103}$ Under its effect, the Council of Lateran IV (I2I5) repudiated any participation

96 COD 444-445.

97 Dictionnaire de droit canonique, IV. 1231-1244.

98 BW 2. 77: "Item pronuntiandum est, ut sciant tempora feriandi per annum, id est omnem Dominicam a vespera usque ad vesperam (...): Natalis Domini sancti Stephani, sancti Joannis evangelistae, Innocentum, octava Natalis Domini, Theophania, Purificatio sanctae Mariae, sanctum Pascha cum tota hebdomada, Rogationes tribus diebus, Ascensio Domini, sancti dies Pentacostes, sancti Joannis Baptistae, duodecim apostolorum, maxime tamen sanctorum Petri et Pauli, qui mundum sua predicatione illuminaverunt, sancti Laurentii, Assumptio sanctae Mariae, Nativitas sanctae Mariae Virginis, Dedicatio basilicae sancti archangeli Michaelis, Dedicatio cujuscumque oratorii et omnium sanctorum, et sancti Martini, et illae festivitates quas singuli episcopi in suis episcopalis cum populo collaudaverint, quae vicinis tantum circcum morantibus indicendae sunt, non generaliter omnibus (...)." PL CXL. 640 .

99 Synodus Szabolchensis (1092), Cap. XXXVIIII: “(...) sancti Stephani regis, Bartholomei apostoli, Nativitatis sancte Marie, Exaltacio sancte crucis, sancti Mathei apostoli, sancti Gerardi episcopi (...).” Závodszky, p. 164.

${ }^{100}$ Synodus Szabolchensis (1092), Cap. XXVIII: Quocienscumque vel aqua vel fero iudicium factum fuerit, intersint ibi tres ydonei testes iureiurando probati, qui et innocentis innocenciam, et e contra culpabilis culpam pergibeant. Presbiter de ferro duas pensas et de aqua unam pensam accipiat.” Závodszky, p. 162.

${ }_{101}$ Cf. P. Erdö, Storia della scienza del diritto canonico. Una introduzione, Roma 1999, p. 53.

102 J. Gaudemet, Église et cité. Histoire du droit canonique, Paris 1994, p. 522; Sz. A. Szuromi, Az egyházi intézményrendszer története, pp. 215-216.

103 A. Potthast, (ed.), Regesta Pontificum Romanorum inde ab a. post Christum natum MCXCVIII ad a. MCCCIV, I-II. Berlin 1875 (repr. Graz 1957) no. 2785; cf. J.Gaudemet, Église et cité, 522; Sz. A.Szuromi, Medieval Canon 
of clerics in forms of contestations that were often used in secular penal procedures ${ }^{104}$, as in fire ordeal or hot water ordeal. Moreover, it forbade for priests to bless the means used for purgatio. ${ }^{105}$

\section{Conclusion}

On the ground of the above presented historical, political, canon-historical, and textual critical context, it is well discernible that the convocation and legislation of the Council of Szabolcs followed those Hungarian traditions that came from times foregoing the rule of St. Ladislaus and reaching back to St. Stephan. In the case the surviving manuscripts preserved indeed the text of an imperial-council, then its two most important sources are - beyond the earlier Hungarian ecclesiastical legislation - the Decretum Burchardi Wormatiensis and that imperial legislation concerning the Church which is summarized in the Frank-German "capitula" and "constitutiones". This confirms our previously more times explained standpoint that chapters standing close to the Eastern discipline are not to be considered as consequences of the influence of the Byzantine Church, but more probably they are results of an earlier disciplinary material found in such universal canonical collections which were used in the Hungarian councils. The Council of Szabolcs was designated to comprehensively and stably arrange the Hungarian ecclesiastical relations but it was far from taking over the Gregorian reforms. The reception of the canonical reform that was confirmed by Pope Gregory VII and his successors, and its application on both legislative and practical level began gradually during the reign of King Coloman (I095-III6) with the enactment of the decrees of the First and Second Council of Esztergom, which course of transformation reached its end on the Third Council of Esztergom in II69, in the presence of the papal legate.

\section{St. King Ladislaus and the Council of Szaboles (1092) Summary}

The present article examines the council of Szabolcs (I092) on the political, legal and ecclesiastical field. Firstly, the conciliar and canonical disciplinary background in Hungary is explained in order to show in the next part of the paper the importance, proceeding and provisions of the council of Szabolcs. Then, the precise survey of proceeding and provisions of the council is made with analysis of the content of the chapters and their textual correlation.

Law - Sources and Theory - (Bibliotheca Instituti Postgradualis Iuris Canonici Universitatis Catholicae de Petro Pázmány nominatae III/12), Budapest 2009, pp. 151-153.

104 Magyar jogtörténet, B. Mezey, (ed.), Budapest 1996, p. 224, 231. The Cathedral Chapter of Magnovarad as place of authentication (locus credibilis) had registered those processes of verification which had happened there between 1208 and 1235. It had been summarized in the so called Regestrum Varadinense. The majority of processes, within this register, describes processes of verification in some form of cases of ordeal, even the clear and strict canonical prohibition, cf. J. Karácsonyi, S. Borovszky, (eds.), Regestrum Varadinense. Examen ferri candentis ordine chronologico digestum descripta effigie editionis a. 1550 illustratum, Budapest 1903; cf. Korai magyar történeti lexicon, Gy. Kristó, (ed.), p. 713.

105 Conc. Lateranense IV, Const. 18: (...) "Nullus quoque clericus rottariis aut balistariis aut huiusmodi viris sanguinum praeponatur, nec illam chirurgiae artem subdiaconus, diaconus vel sacerdos exerceant, quae ad ustionem vel incisionem inducit, nec quisquam purgationi aquae ferventis vel frigidae seu ferri candentis ritum cuiuslibet benedictionis aut consecrationis impendat, salvis nihilominus prohibitionibus de monomachiis sive duellis antea promulgatis." COD 244. 
In the conclusion is stressed that the council's chapters standing close to the Eastern discipline are derived from universal canonical collections, and that the above-mentioned council should be regarded as first step in the longer process of reception of the Gregory VII's canonical reform.

Keywords: Canonical law, medieval Hungary, council, Szablocs, Gregory VII, king Ladislaus

\section{Król Władysław I Święty i synod w Szablocs (1092)}

\section{Abstrakt}

Niniejszy artykuł skupia się na omówieniu synodu w Szabolcs (I092) na gruncie problematyki politycznej, prawnej i kościelnej. W pierwszej części tekstu wyjaśniona jest myśl i praktyka prawno-kanoniczna na Węgrzech, aby w kolejnej przejść do charakterystyki znaczenia, przebiegu i postanowień synodu w Szablocs. Następnie zostaje przeprowadzona szczegółowa analiza przebiegu i postanowień oraz związków pomiędzy poszczególnymi kanonami. W podsumowaniu jest podkreślone, iż postanowienia zbliżone w swoim kształcie do wschodniego kształtu dyscypliny kościelnej podjęte na omawianym synodzie wynikają przede wszystkim z bazowania na wówczas stosowanych ogólnych zbiorach prawno-kanonicznych, a także że synod w Szablocs stanowił pierwszy krok w dłuższym procesie recepcji reformy zapoczątkowanej przez Grzegorza VII.

Słowa kluczowe: Prawo kanoniczne, średniowieczne Węgry, synod, Szabolcs, Grzegorz VII, król Władysław

\section{BIBLIOGRAFIA}

Bartlett R., The Making of Europe. Conquest, Colonization and Cultural Change 950-I350, Harmondsworth I994, s. 60-84.

Blumenthal U-R., The Papacy and Canon Law in the Eleventh-Century Reform, „Catholic Historical Review" 84 (I998), s. 20I-2I8.

Constable G., Past and Present in the Eleventh and Twelfth Centuries: Perceptions of Time and Change, in: L'Europa dei secoli XI e XII fra novità e tradizione. Sviluppi di una cultura (Miscellanea del centro di studi medioevali I2), Milan I989 s. I35-I70.

Dură N., The Ecumenity of the Councill in Trullo: Withesses of the Canonical Tradition in East and West, in: Nedungatt G., Featherstone M. (eds.), The Council in Trullo revisited (Kanonika 6), Roma I995, s. 229-262.

Erdő P., Az egyházmegyei zsinat intézménye a történelemben, in: Erdő P., Egyházjog a középkori Magyarországon, Budapest 200I, s. I9-24.

Erdö P., Storia della scienza del diritto canonico. Una introduzione, Roma 1999, s. 53.

Erdö P., Storia delle Fonti del Diritto Canonico (Istituto di Diritto Canonico San Pio X, Manuali 2), Venezia 2008, s. 7I-72.

Faulkner, Th., Law and Authority in the Early Middle Ages. The Frankish leges in the Carolingian Period, Cambridge 20I6, s. 46-47.

Fejér G. (ed.), Codex Diplomaticus Hungariae ecclesiasticus ac civilis, Buda I829, s. 420. 
Fowler-Magerl L., Clavis Canonum. Selected Canon Law Collections Before II40 (MGH Hilfsmittel 2I), Hannover 2005, S. I57-I58.

France J., Patronage and the appeal of the First Crusade, in: Phillips J. (ed.), The First Crusade. Origins and impact, Manchester-New York 1997. 5-20.

Fuhrmann H., Einfluss und Verbreitung der pseudoisidorischen Falschungen, III (MGH Schriften XXIV/3), Stuttgart I974, s. 784-I005.

Fuhrmann H., Germany in the High Middle Ages c. I050 - I200 (transl. Reuter, T.), Cambridge I995, s. 73-77.

Gaudemet J., Église et cité. Histoire du droit canonique, Paris I994, s. 522.

Hinschius P. (ed.), Decretales Pseudo-Isidorianae et Capitula Angilramni, Lipsiae I863, S. 22-24.

Hinschius P. (ed.), Decretales Pseudo-Isidorianae et Capitula Angilramni, Lipsiae I863.

Kéry L., Canonical Collections of the Early Middle Ages (ca. 400-II40). A Bibliographical Guide to the Manuscripts and Literature (History of Medieval Canon Law I), Washington, D.C. I999, s. I00-II4.

Komáromi L., A bizánci hatás kérdése a középkori magyar jogban és a magyarországi egyházjogban, Budapest 20I3, s. I04-I20.

Kostick C., The Social Structure of the First Crusade, Leiden-Boston 2008, s. I59-I86.

Kristó G. (ed.), Korai magyar történeti lexikon, Budapest I994, s. 527, 59 I.

Kristó, Gy., Magyarország története 895-I30I, Budapest I998, s. 96-97.

Makk F. - Thoroczkay, G. (eds.), Írott források az I050-III6 közötti magyar történelemből (Szegedi Középkortörténeti Könyvtár 22), Szeged 2006, s. 85, I46-I47.

Mezey B. (ed.), Magyar jogtörténet, Budapest I996, s. 224, 23I.

Mikó G., Szent István király törvényeinek legrégibb kézirata. Az Admonti kódex, in: Bárány A., Dreska G., Szovák K. (eds.), Arcana tabularii: Tanulmányok Solymosi László tiszteletére, II. Debrecen-Budapest 20I4, s. 723-732.

Mikó G., Szent István törvényeinek XVI. századi kézirata Lőcse város levéltárában, „Fons: Forráskutatás és történelmi segédtudományyok" I8/2 (20II), S. III-I45.

Patrologiae cursus completus. Series Latina (ed. I-P. MIGNE, I-CCXXI, Lutetiae Parisiorum I844-I864.

Péterffy C. (ed.), Sacra concilia Ecclesiae Romano - Catholicae in Regno Hungariae celebrata, Posonii I742, S. I-I3.

Plöchl W., Geschichte des Kirchenrechts, Wien-München I962, s. 88-89, Io8.

Potthast, A. (ed.), Regesta Pontificum Romanorum inde ab a. post Christum natum MCXCVIII ad a. MCCCIV, I-II. Berlin I875 no. 2785.

Somerville R., Pope Urban II's Council of Piacenza, March I-7, I095, Oxford 20 II.

Stickler, A., Historia iuris canonici latini, vol. I. Historia fontium, Roma I950, S. I3I-I40.

Szentirmai A., Die ungarische Diözesansynode im Spätmittelalter, ,Zeitschrift der Savigny-Stiftung für Rechtsgeschichte, Kanonistische Abteilung” 47 (I96I), s. 266-292.

Szuromi Sz. A., A püspökökre vonatkozó egyházfegyelmi szabályok a Dionysio-Hadriana gyüjteményben, „Kánonjog” 2 (2000), s. 87-95, 90, 93.

Szuromi Sz. A., Anselm of Lucca as a Canonist. Critical summary on importance of the Collectio Anselmi Lucensis, „Rivista internazionale di diritto comune” I6 (2005), s. 225-239.

Szuromi Sz. A., Az egyházi intézményrendszer története (Szent István Kézikönyvek I5), Budapest 20I7, s. III-II4. 
Szuromi SZ. A., Az első három Esztergomi Zsinat és a magyarországi egyházfegyelem a XII. században, „Magyar Könyvszemle” II5 (I999), s. 377-409.

Szuromi SZ. A., Fejezetek az egyházi jogalkotás történetéből. Források és intézmények (Bibliotheca Instituti Postgradualis Iuris Canonici Universitatis Catholicae de Petro Pázmány nominatae III/I5), Budapest 20II, s. 86-I00.

Szuromi Sz. A., Some observations on BAV Reg. lat. 325 as a witness of Anselm of Lucca's Collection, „Ius Ecclesiae” I5 (2003), s. 799-8Io.

Szuromi Sz. A., Szempontok az I307. évi Udvardi Zsinat kánonjogtörténeti vonatkozásaihoz, „Iustum Aequum Salutare” IX/2 (20I3), s. I05-IIO.

Szuromi SZ. A., The Constitutions of the Fourth Lateran Council (I2I5) according to its Theological, Canonical and Historical Aspects, „Rivista Internazionale di diritto comune” I5 (2004), s. I85-I99.

Szuromi, Sz. A., Medieval Canon Law - Sources and Theory - (Bibliotheca Instituti Postgradualis Iuris Canonici Universitatis Catholicae de Petro Pázmány nominatae III/I2), Budapest 2009, S. I5I-I53.

Ullmann W., A Short History of the Papacy in the Middle Ages, London I972, s. I42.

Waldmüller L., Die Synoden in Dalmatien, Kroatien und Ungarn. Von der Völkerwanderung bis zum Ende Arpaden (I3II) [Konziliengeschichte A], Paderborn-München-Wien-Zürich I987s. I88-200.

Wasserschleben, R. G. A., Reginonis abbatis Prumiensis Libri duo de synodalibus causis et disciplinis ecclesiasticis, Leipzig I840.

Závodszky L., A Szent István, Szent László és Kálmán korabeli törvények és zsinati határozatok forrásai (függelék: a törvények szövege), Budapest I904, s. I4I-I65. 